\title{
Ethnobotany of Dioscorea L. with emphasis on food value in Chepang communities in Dhading district, central Nepal
}

\author{
Lila Nath Sharma ${ }^{1 *}$ and Rishi Bastakoti ${ }^{2}$ \\ ${ }^{1}$ Central Department of botany, Tribhuvan University, Kirtipur, Kathmandu, Nepal; ${ }^{2}$ RIMS-Nepal, Gajuri, Dhading, Nepal; \\ ${ }^{*}$ Corresponding author, e-mail: lilansharma@yahoo.com
}

\begin{abstract}
Chepang, inhabiting the rugged terrain of Mahabharat and Churia range in central Nepal, is a group of indigenous people suffering from severe food insecurity. Their ancestors lived a semi-nomadic life up to one and half century back. To a large extent, Chepang still continue their traditional way of living, which includes collection of wild tubers ('kandamul'), hunting and fishing. Chepangs are especially connected with the tubers of Dioscorea spp. Wild and cultivated species of Dioscorea are being used as sources of carbohydrates to supplement cereal food. However, dependency on such wild food is decreasing with adoption of agriculture. In this study we documented local knowledge on the diversity and use of Dioscorea species among Chepang in Dhusa and Jogimara Village Development Committees in Dhading district. Ethnobotanical data were collected through semi-structured interviews, forest transect walk and participatory observations. Out of 13 species of Dioscorea reported from all over Nepal, 10 species have been recorded from the study area. Chepang people use one species (Dioscorea deltoidea) as detergent and the rest nine species are exclusively used as food although many of them have multiple utilities. Chepang people have diverse knowledge in the identification, processing and consumption of wild tubers of Dioscorea spp. and such knowledge might have developed as a strategy to combat severe food scarcity. Use of disproportionately higher number of Dioscorea species by a single ethnic group and within a comparatively small territory indicates very close affinity of local cultural practice and the nature. The richness of knowledge associated with wild tubers and high dependency of Chepang on them is the manifestation of severe food insecurity and traditional mode of life due to their social and economic isolation for long time.
\end{abstract}

Key-words: food insecurity, indigenous knowledge, tubers, wild edible plants.

\section{Introduction}

In many indigenous societies edible plant use is an ancestral tradition (Ladio and Lozada 2003). Knowledge and patterns of wild plant use in human societies depend on their socio-cultural aspects and ecological conditions of the gathering environments (Somnasang and Moreno-Black 2000; Ladio and Lozada 2004). Indigenous people also gain knowledge associated with collection, harvest, processing and utilization of wild edibles as a strategy to cope with food scarcity. Chepang are important in this connection as they are a group of people highly dependent on wild edibles and are least influenced by modern agriculture. Furthermore, Chepang are considered to be the youngest communities to instigate agriculture in Nepal (HMG 1974).

Chepang are known as people living in hills with difficult physiography (Rai 1985; Thapaliya 1987). They sometimes call themselves by the name Chebang or Chyobang ('Chyo' means 'on the top', and 'Bang' means stone). Chepang, including other three ethnic groups (Kusunda, Darai and Kumal), are also known by the term 'Praja' (Rai 1985). The term Praja came after a program called 'Praja development program' run by government during 1980s (Rai 1985).

Chepang are one of the deprived ethnic groups in minority living in central Nepal. Chepang live in their traditional territories consisting of southern part of Dhading and Gorkha districts, western part of Makawanpur district, and northern part of Chitwan district (Bista 1976). Their traditional settlements lie on steep slopes in the Mahabharat and Churia range between 500 to $1500 \mathrm{~m}$ asl. However, these days Chepang settlements are also found below $500 \mathrm{~m}$ asl. Two modes of agriculture are practiced in Chepang community; the first one is their indigenous slash-and-burn farming, and the second one is terrace farming in permanent agricultural land. According to Caughley et al. (1971) Chepang started agrarian life only recently i.e. some 120 years ago; before that they used to live partly in forests and caves. In their life, maize is the most important crop, followed by millet. In spite of their hard work, the barren and less fertile land does not yield enough food. The maize production can suffice only six months in a year (Gurung 1995). In recent years, Chepang have also started commercial vegetable farming on small scale. The important hindrance in their agro-practice is unavailability of irrigation facility (Gharti-Magar 2005). Similarly, insufficient land with difficult topography, poor land husbandry and their traditional life style are other factors limiting food production. Large labor input in agriculture hardly supports their subsistence even at present. Therefore, as a part of their traditional life style, Chepang still rely on wild food sources, especially tubers and roots ('kandamul'), for subsistence.

Chepang collect wild yam (Dioscorea spp.) and other plants to substitute even cereal foods during the period of food insufficiency. Besides yam, the other edible forest products collected by 
Chepang consist of 'tanki' (Bauhinia purpurea L.), 'sisnu' (Urtica dioica L.), 'niuro' (Diplazium sp., Dryopteris sp.), 'chiuri ko phool' (Diploknema butyracea (Roxb.) H.J. Lam), 'tama' (Dendrocalamus sp.), 'chyau' (Agaricus sp.) and 'jalugo' (Alocasia sp.) (Gurung 1995).

Studies have been carried out on Chepang communities particularly after 1970. Most of the studies, however, were related to their socio-culture (Caughley et al. 1971; Dhungel 1994; Gurung 1995). Rai (1985) and Gurung (1995) have given relatively more information about the food culture and ethnoecology of Chepang people. Manandhar (1989), Basnet et al. (2001) and Karki (2001) documented ethnomedicinal uses of plants. None of these studies explored scientifically all the species of Dioscorea used by Chepang neither they gave detail account on people's interaction with tubers of wild Dioscorea spp. So there exists a research gap pertaining to specific study on ethnobotany of wild Dioscorea spp. Present paper attempts to document indigenous knowledge of Chepang on the diversity and use of yam (Dioscorea spp.) and assess their dependency on traditional foods.

\section{Materials and Methods}

\section{STUDY AREA}

Study was carried out in four Chepang villages in two Village Development Committees (VDCs), namely Dhusa and Jogimara of Dhading district of central Nepal. Both of the VDCs lie in the extreme southwest of the respective district. In Dhusa VDC, study was carried out in Dukrang and Yarbang villages, and in Jogimara VDC, Jawang and Mangrang villages were selected. Geographically the study area lies in the Mahabharat range between the altitudes of 600 and $1300 \mathrm{~m}$ asl.

The natural vegetation mainly comprises Shorea robusta forest. Above Shorea robusta forest zone (i.e., >1000 m), broadleaved forests of Schima wallichii and Castanopsis indica occur. Natural forests in this area are highly fragmented and pure forest stands rarely occur. The area is primarily steep and people reside on the top and back slope of the mountain. Tropical type of climate prevails at the lower elevation ( $<1000 \mathrm{~m}$ asl $)$ and subtropical climate in higher elevations (1000-1500 m asl). People dwelling in this area are mostly subsistence farmers. Agriculture, animal husbandry, wild food gathering, and wage laboring are important aspects of their economic activities. Maize is the main crop, which is supplemented by millet. As agricultural food production does not support peoples' livelihood throughout the year, some of the people work as wage laborer in local market and limestone mine in Jawang khola.

YAM (DIOSCOREA SPP.)

Species of Dioscorea (family: Dioscoreaceae), commonly called yam, are food plants of tropics and subtropics. In Nepal, Dioscoreaceae has only one genus Dioscorea with 13 species, of which, two are cultivated (Press et al. 2000). In Nepal, its members are distributed in tropical and subtropical zones. Members of the genus Dioscorea are left or right twinning climbers with round to winged stem. They bear one to many tubers of different shape. Most of them bear bulbils in the leaf axils, which in most cases act as vegetative propagules. Leaves are opposite or alternate, simple or compound; if compound they are tri- to penta-foliate. Plants are dioecious, and male and female flowers are born on spikes. Fruits are generally three winged.

\section{DATA COLLECTION}

Ethnobotanical data on wild and cultivated Dioscorea species were collected through group discussions and semi-structured interviews with local elderly people during February-September of 2007. In total, three field visits (February, June and September) were made and 20 elderly people were interviewed. During interviews and group discussions, we explored the system of identification and nomenclature of Dioscorea species, their food value and other uses, level of toxicity, and mode of processing. In addition, we also carried out forest transect walk (one transect walk in each village) with key informants ( $n=3-5)$ to observe the method of collection of wild tubers. Moreover, we inspected tubers collected by local people in the village to get an idea about species collected from forest and their use at household level. Plant specimens were photographed and collected during forest transect walk and identified with the help of standard literature (Noltie 1994; Zhengyi 2000). Some specimens were later reconfirmed at national herbarium (KATH). Collected specimens were deposited at Tribhuvan University Central Herbarium(TUCH).

\section{Results}

\section{SPECIES OF DIOSCOREA}

We reported eight species of Dioscorea from wild and two from cultivation (Table 1), which are collected and used by Chepang people. Seven wild species were identified up to species level and one species (locally known as 'chuinya') remain unidentified. Most of the species are used as food, although they may have medicinal and other use values. $D$. deltoidea is the only non-edible species recorded in this study. The most preferred and valuable edible species is $D$. hamiltonii. Except $D$. hispida, other edible species are not poisonous.

\section{LOCAL KNOWLEDGE IN IDENTIFICATION AND CLASSIFICATION}

Chepang have considerable knowledge in recognizing wild tuberous plants. They not only collect safe tubers from wild but also the poisonous ones. Proper identification is necessary to treat the tubers according to their nature. This knowledge helps them to make distinction between poisonous and non-poisonous tubers and they 
process tubers accordingly. They are highly skillful in processing the poisonous tubers so as to decoct the poison. Beside Chepang names, people also know Nepali names of all Dioscorea spp. they use. Elderly people can easily distinguish different species as different 'jat' (type). They sometimes even distinguish variations within a 'jat' (Table 1). The basis of differentiation is the observation of texture of leaves; color, shape and taste of tubers; and presence or absence of roots on the tuber.

People have broadly classified locally known species of Dioscorea into three groups, depending on the nature of tubers and leaf morphology: plants with round tubers are known by the name 'lac' (Nepali name 'githa'), plants possessing pentafoliate leaves are called 'pas' (Nepali name 'bhyakur'), and those with long tuber are known as 'goi' (Nepali name 'tarul'). All the cultivated yams are known as 'goi'. Members of these three groups have been further distinguished and given local names: 'lac' (D. bulbifera) has been divided into 'hyac lac' (bitter variety) and 're lac' (sweet variety), depending on the taste of tubers and leaf texture (rough in the case of 'hyac lac' and smooth in 're lac'); 'pas' (D. pentaphylla) is divided into ‘ja pas'(variety with fibrous and reddish tuber) and 'suti pas' (variety with fleshy and whitish tuber), depending on the nature of tubers; 'goi' has been divided into 'kim goi' (cultivated) and 'bran goi' (forest/wild) based on habitat.

Although the term 'bran' means forest and the yam growing in the forest are called 'bran goi' ( $D$. hamiltonii is specifically known by this name), there are other forest species of Dioscorea belonging to 'goi' group but are named differently. For example, 'kui goi' $(D$. deltoidea; 'kui' literally means dog) and 'panglang goi' (D. pubera). The cultivated 'jat' includes two species of 'goi' (D. esculenta and D. alata) and locally they are further divided based on orientation of tuber beneath soil surface; color and number of tuber; and leaf shape and texture. There are more than 15 locally named varieties of cultivated tubers of Dioscorea (data not shown). However, nomenclature of cultivated varieties of yam rarely exist in Chepang language, instead mostly they use Nepali terms.

HARVESTING PRACTICES AND PROCESSING

People visit forests, individually or in groups, to collect tubers of Dioscorea spp. Tubers are mostly harvested during February to May. However, few people with insufficient food production start collection earlier than this period. Although people are aware of the decreasing condition of the resource in the wild, they heavily collect masses of tubers from mature plants inhibiting vegetative propagation. In such condition, plant regeneration takes place only through bulbils if they get chance to grow. Sometimes tubers are harvested even before the growth of bulbils. People harvest above ground parts of the plant as fodder so that plant may be destroyed prior to the formation of bulbils. Poisonous species, like $D$. hispida, are rigorously processed prior to consumption. Other bitter species are consumed after proper boiling.
MODES AND METHODS OF USE

The tubers and bulbils of Dioscorea spp. are used in different forms. The aerial parts of all species, except those of $D$. hispida, are palatable to cattle hence such plant parts are used as fodder. All the 10 species of Dioscorea are enumerated below by their Chepang name, followed by botanical name, Nepali name and detail use and methods of processing.

\section{1. 'bas goi’: Dioscorea esculenta (Lour.) Burkill}

Nepali name: kande tarul

Tubers and bulbils are edible and used for culinary purpose as vegetable or main meal.

\section{2. 'bran goi' or 'ban goi’: Dioscorea hamiltonii Hook. f. \\ Nepali name: ban tarul}

Tubers and bulbils are edible. It is the most delicious and highly valued yam among Chepang. Tubers are consumed as vegetable or as snack and as staple food item. It can be eaten raw without cooking. Bulbils are also eaten as vegetable.

Crushed tubers are given as body refrigerant during summer season. Besides, it is considered good in case of diarrhea. The plant is also offered to god in religious activities.

\section{3. 'glhi': Dioscorea kamoonensis Kunth}

Nepali name: tyaguna

Bulbils and tuber are edible. Tubers are boiled and eaten as vegetable, or as snack and main meal. It is also mixed with 'hung' (Dioscorea hispida) while boiling to reduce the poison of 'hung' (see below). It is also consumed when symptoms of poisoning appear after consuming 'hung'.

\section{4. 'hung': Dioscorea hispida Dennst. \\ Nepali name: bharlang}

This plant possesses poisonous tubers which are consumed by Chepang at the time of severe food shortage. The tubers are profusely boiled after cutting. People believe that if tubers of 'glhi' (Dioscorea kamoonensis) are mixed with its tubers while boiling, the toxicity will be reduced. People cover hands with clothes or plastics before removing the outer layer of the tuber otherwise it may damage the skin. The boiled chops of the tuber are dipped in running water at least for 24 hours to make the tubers ready for consumption.

The tubers are eaten as main meal instead of rice. Tubers are also powdered after crushing and eaten as ‘dhindo' (porridge). Tubers are also used to make alcohol after processing. People reported that good quality alcohol can be obtained if grains are mixed with tubers.

Sap of tubers is pasted around the affected parts and covered with clothes for about one night to treat 'harinad' (peeling of skin of feet). Tubers are also considered to be diuretic but are not used for therapeutic purpose. 
5. 'jyar': Dioscorea sp.

Nepali name: chuinya

Tubers are eaten like other species after boiling. It has allergic sap; therefore people take precaution while handling the tubers. Its crushed tubers are mixed with tubers of $D$. pentaphylla and the mixture is used as anthelmintic to treat thread worms and Ascaris.

\section{6. 'kim goi’' Dioscorea alata L.}

Nepali name: ghar tarul

Many local varieties are grown and used. Tubers and bulbils are edible and used for culinary purpose as vegetable or main meal.

\section{7. 'kui goi’: Dioscorea deltoidea Wall. ex Griseb.}

Nepali name: kukur tarul

It is not consumed as food because of hard and fibrous tubers. Tubers are crushed and used as soap. Paste of tuber is also used to kill body lice. It was heavily used to wash clothes before soap was available.

\section{8. 'lac': Dioscorea bulbifera L.}

Nepali name: githa

Local people distinguished sweet and bitter varieties of this species. Tubers of the sweet variety are eaten after boiling only once. Tubers of the bitter variety are eaten after boiling 2-3 times with ash. Tubers and bulbils are eaten as vegetable, or as snack or main food item. It is also taken as refrigerant to reduce body heat during summer. Its powder is used as component of local medicine for tuberculosis.

\section{9. 'panglang goi': Dioscorea pubera Blume}

Nepali name: panglang tarul

Lower half of the tuber is edible. Tubers are consumed as vegetable, or as snack or main food. Upper half of the tuber is avoided as it is much fibrous and stiff.

\section{0. 'pas': Dioscorea pentaphylla L.}

Nepali name: bhyakur

Two types of 'pas' were reported: 'ja pas' (Nepali name: 'jagalte bhyakur') and 'suti pas' (Nepali name: 'rani bhyakur') based on the nature of tubers. 'suti pas' possess much delicious and fleshy tubers, while 'ja pas' has somewhat fibrous and less delicious tubers. The former was preferred by the people over the latter. Tubers are consumed after boiling as vegetable, or as snack and main meal. Bulbils are also eaten as vegetable.

Tubers are used to cure worm infestation in stomach. Crushed mass of tuber is given to cattle when they become sick by eating green leaves of maize. Raw tuber is given to cattle to cure 'vyagute rog' (diphtheria).

Table 1. Species diversity within Dioscorea and their general morphology.

\begin{tabular}{|c|c|c|c|c|c|c|c|}
\hline $\begin{array}{l}\text { Chepang } \\
\text { name }\end{array}$ & $\begin{array}{l}\text { Nepali } \\
\text { name }\end{array}$ & Botanical name & Local varieties & Stem morphology* & Leaf morphology & Tubers & $\begin{array}{l}\text { Voucher } \\
\text { number }\end{array}$ \\
\hline bas goi*** & $\begin{array}{l}\text { kande } \\
\text { tarul }\end{array}$ & $\begin{array}{l}\text { Dioscorea esculenta } \\
\text { (Lour.) Burkill }\end{array}$ & & $\begin{array}{l}\text { Left twinning, round } \\
\text { and prickly }\end{array}$ & Simple, alternate, hairy & $\begin{array}{l}\text { Multiple tubers } \\
\text { protected by crown of } \\
\text { thorny roots }\end{array}$ & NA \\
\hline bran goi & ban tarul & $\begin{array}{l}\text { Dioscorea hamiltonii } \\
\text { Hook.f. }\end{array}$ & & $\begin{array}{l}\text { Right twinning, winged } \\
\text { to round }\end{array}$ & $\begin{array}{l}\text { Simple, mostly } \\
\text { opposite, slightly } \\
\text { saggitate or cordate }\end{array}$ & Multiple, cylindrical & $\begin{array}{l}\text { D107, } \\
\text { TUCH }\end{array}$ \\
\hline hung & bharlang & $\begin{array}{l}\text { Dioscorea hispida } \\
\text { Dennst. }\end{array}$ & & $\begin{array}{l}\text { Left twinning round } \\
\text { stem with recurved } \\
\text { prickles, bulbils absent }\end{array}$ & $\begin{array}{l}\text { Alternate, trifoliate, } \\
\text { middle asymmetric }\end{array}$ & $\begin{array}{l}\text { Single, ovoid or } \\
\text { stalked }\end{array}$ & NA \\
\hline jyar & chuinya & Dioscorea sp. & & $\begin{array}{l}\text { Left twinning, round, } \\
\text { slightly prickly }\end{array}$ & $\begin{array}{l}\text { Alternate, trifoliate, } \\
\text { leaflets ovate, lateral } \\
\text { asymmetric }\end{array}$ & $\begin{array}{l}\text { Single, cylindrical, } \\
\text { fibrous tuber }\end{array}$ & NA \\
\hline kui goi & $\begin{array}{l}\text { Kukur } \\
\text { tarul }\end{array}$ & $\begin{array}{l}\text { Dioscorea deltoidea } \\
\text { Wall. ex Griseb. }\end{array}$ & & $\begin{array}{l}\text { Left twinning round } \\
\text { stem }\end{array}$ & $\begin{array}{l}\text { Simple, deltoid to } \\
\text { cordate }\end{array}$ & $\begin{array}{l}\text { Horizontal, cylindrical, } \\
\text { branched }\end{array}$ & $\begin{array}{l}\text { D105, } \\
\text { TUCH }\end{array}$ \\
\hline lac & Githa & $\begin{array}{l}\text { Dioscorea bulbifera } \\
\text { L. }\end{array}$ & $\begin{array}{l}\text { hyac lac (bitter) and re lac } \\
\text { (sweet variety) }\end{array}$ & $\begin{array}{l}\text { Left twinning winged } \\
\text { stem }\end{array}$ & $\begin{array}{l}\text { Simple, alternate, } \\
\text { cordate }\end{array}$ & Rounded, single & $\begin{array}{l}\text { D102, } \\
\text { TUCH }\end{array}$ \\
\hline $\begin{array}{l}\text { panglang } \\
\text { goi }\end{array}$ & $\begin{array}{l}\text { panglang } \\
\text { tarul }\end{array}$ & $\begin{array}{l}\text { Dioscorea pubera } \\
\text { Blume }\end{array}$ & & $\begin{array}{l}\text { Right twinning, round, } \\
\text { hairy }\end{array}$ & Simple alternate & $\begin{array}{l}\text { Single, cylindrical- } \\
\text { conical, deeply buried }\end{array}$ & NA \\
\hline pas & bhyakur & $\begin{array}{l}\text { Dioscorea } \\
\text { pentaphylla L. }\end{array}$ & $\begin{array}{l}\text { ja pas (fibrous tuber) and } \\
\text { suti pas (fleshy tubers) }\end{array}$ & $\begin{array}{l}\text { Left twinning, round } \\
\text { stem }\end{array}$ & Alternate, pentafoliate & Single, stalked & $\begin{array}{l}\text { D112, } \\
\text { TUCH }\end{array}$ \\
\hline
\end{tabular}

*bulbils present unless specified; **NA - voucher specimens not collected or not properly preserved; *** cultivated species; ${ }^{\ddagger}$ for Dioscorea alata more than 15 local varieties exist (personal communication with Prem Bahadur Chepang and Jawang of Jogimara). 


\section{Discussion}

FOOD INSUFFICIENCY AND COLLECTION OF DISOCOREA

The starchy reserves of yams are a principle source of carbohydrates for many different indigenous societies living in the tropics and subtropics of the world (Dounias 2001). However, as reported in the present study, a number of other non-food uses of wild yams have also been documented (reviewed in Dounias 2001). Chepang are also traditionally depending on collection of tubers as well as other wild edibles for their livelihood. Wild yams are principal source of starch and prominent staple food during food shortage. Most Chepangs have limited land for agriculture which tend to be forest land and terraces of poor quality on steep slopes around their houses. Therefore, they have food sufficiency for only about six months in a year and for the rest of the year people depend on wild plants (Rai 1985; Gurung 1995). It was found that the time and duration of yam collection depend on household food sufficiency. Mostly people collect wild tubers during February to May. During this period many families lack grains. Some of the people even start collection from October. However, such traditional mode of subsistence is gradually changing and is on the way to further change in the course of social transformation (Gurung 1989).

\section{LOCAL CLASSIFICATION AND KNOWLEDGE ON YAM TUBERS}

Different indigenous societies in the word group plant or animal by similarities and differences, producing a system of hierarchical classification with different levels of decreasing order of life form, generic and specific (Berlin et al. 1966; Berlin 1992; Holman 2002). Elderly Chepang people not only accurately identify and group different species of Dioscorea in their own local term but even recognize different varieties within single species (e.g., Dioscorea alata, D. bulbifera and $D$. pentaphylla). Such knowledge is useful in the selection of proper variety and processing for culinary purpose. The prior identification is very important particularly to process deadly poisonous species, like $D$. hispida. Furthermore, a number of names for plant varieties within folk taxonomy reflect the large genetic diversity of the concerned species (Clement 1980; Kerr and Posey 1984; Sambatti et al. 2001).

\section{DIOSCOREA SPECIES RECORDED}

Out of 13 species of Dioscorea reported from Nepal, Chepang people in the study area use 10 species ( 9 species as food and 1 species for other purposes), of which, 8 species are obtained from the wild and 2 are cultivated (D. esculenta and D. alata). This figure may increase with further research. In a previous study, Karki (2001) reported the use of only two species (D. bulbifera and $D$. deltoidea) from Dhusa VDC. Similarly Aryal (2007) reported five species of uncultivated Dioscorea from the Dhusa area. Our study has explored the use of eight wild species found in the same VDC. These finding reveals that the study area is extraordinarily rich not only in the diversity of Dioscorea species but also in the knowledge pertaining to the use of their tubers. This richness of knowledge associated with the use is a manifestation of the close affinity of Chepang with wild tubers and an indication of their food culture.

Beside species diversity, this study has corrected the identity of $D$. hispida which has been identified previously by other name (Joshi 2004; Basnet et al. 2001). Many studies (HMG 1982; Rai 1985; Basnet et al. 2001; Aryal 2007) have mentioned D. deltoidea as edible species but findings of present study contradict with this. We did not find any response and hints for the culinary use of this species. Due to the presence of hard and fibrous tubers and its poisonous nature people do not prefer $D$. deltoidea for culinary purpose. Extract of its tubers are mostly used as soap and as insecticide.

\section{Conclusions}

Present paper has documented indigenous knowledge of Chepang on the diversity and use of yam (Dioscorea spp.) and helped to improve our understanding on their dependency on traditional foods. Chepang people are highly knowledgeable in terms of identification, collection, processing and consumption of wild tubers of Dioscorea and such knowledge might have developed as a strategy to combat the severe food scarcity in the villages. Use of disproportionately higher number of Dioscorea species by a single ethnic group and within a comparatively small geographical area (including four Chepang villages in two VDCs) indicates very close affinity of local cultural practice and the natural world. Chepang people remained away from social and economic mainstream for long time and traditionally suffered from high level of food scarcity, which compelled them to rely on wild tubers for much part of the year. Therefore, the richness of knowledge associated with wild tubers and high dependency of Chepang on them is the manifestation of severe food insecurity and traditional mode of life due to their social and economic isolation for long time.

\section{Acknowledgements}

We would like to acknowledge UNDP/GEF/SGP-supported Agrobiodiversity Conservation Program of RIMS-Nepal, Baireni, Dhading for providing financial and logistic supports for our field study. We are highly indebted to Dr. Suresh K. Ghimire for providing critical academic input to improve the manuscript. We thank all the local people who supported our study by sharing valuable information and time.

\section{References}

Aryal K.P. 2007. Uncultivated Plants: an Option for Livelihood Support of the People in Mid-hills of Nepal. Masters Thesis. International Master Program, Swedish Biodiversity Centre, Uppsala University, Sweden.

Basnet B., Joshi R. and Lekhak H.D. 2001. Ethnobotanical survey of Chepang tribe of Makwanpur district, Nepal. In: Environment and Agriculture: Biodiversity, Agriculture and Pollution in South Asia. (P.K. Jha, S.R. 
Baral, S.B. Karmacharya, H.D. Lekhak, P. Lacoul and C.B. Baniya, eds.), pp. 245-252. Ecological Society (ECOS), Kathmandu, Nepal.

Berlin B. 1992. Ethnobiological classification: Principles of categorization of plants and animals in traditional societies. Princeton University Press, Princeton, New Jersey, USA.

Berlin B., Breedlove D.E. and Raven P.H. 1966. Folk taxonomies and biological classification. Science 154: 273-275.

Bista D.B. 1976. People of Nepal. Ratna Pustak Bhandar, Kathmandu, Nepal.

Caughley R.C., Dahal B.M. and Bandhu C.M. 1971. Notes on Chepang culture. Journal of Tribhuvan University 6(1): 77-89.

Dhungel R.M. 1994. Chepang Samudaya ra Sanskriti. Sajha Prakasan, Kathmandu, Nepal (in Nepali).

Dounias E. 2001. The management of wild yam tubers by the Baka Pygmies in southern Cameroon. African Study Monographs, Suppl. 26: 135-156.

Gharti-Magar R.P. 2005. Chepangko Parichaya. Shrijana Gharti Magar and Dhan Maya Gharti Magar, Kathmandu, Nepal (in Nepali).

Gurung G.M. 1989. The Chepangs: A Study in Continuity and Change. Center for Nepal and Asian Studies (CNAS), Tribhuvan University, Kathmandu, Kathmandu, Nepal.

Gurung G.M. 1995. Report from a Chepang Village: Society, Culture and Environment. S. Gurung, Kathmandu, Nepal.

HMG 1974. Mechidekhi Mahakali. Part II. Suchana Bivag, Ministry of Communication, His Majesty Government of Nepal, Kathmandu, Nepal.

HMG 1982. Wild Edible Plants of Nepal. Department of Plant Resources, His Majesty's Government of Nepal, Kathmandu, Nepal.

Holman E.W. 2002. The relation between folk and scientific classifications of plants and animals. Journal of Classification 19(1): 131-159.

Joshi R. 2004. Nutrient composition of some wild edible plants used by Chepang tribes of Makwanpur district, Nepal. Botanica Orientalis 4(1): $72-78$.
Karki L. 2001. Documentation of Indigenous Knowledge on the Utilization of Plant Resources by the Chepang Community of Dhusa VDC, Dhading, Central Nepal. M.Sc. Thesis. Central Department of Botany, Tribhuvan University, Kirtipur, Kathmandu, Nepal.

Ladio A.H. and Lozada M. 2003. Comparison of wild edible plant diversity and foraging strategies in two aboriginal communities of northwestern Patagonia. Biodiversity and Conservation 12: 937-951.

Ladio A.H. and Lozada M. 2004. Patterns of use and knowledge of wild edible plants in distinct ecological environments: a case study of a Mapuche community from northwestern Patagonia. Biodiversity and Conservation 13: $1153-1173$.

Manandhar N.P. 1989. Medicinal plants used by Chepang tribe of Makwanpur district, Nepal. Fitoterapia 60(1): 61-68.

Noltie H.J. 1994. Flora of Bhutan Including Records of Plants from Sikkim and Darjeeling. Vol 3, Part 1. Royal Botanical Garden, Edinburgh, UK.

Press J.R., Shrestha K.K. and Sutton D.A. 2000. Annotated Checklist of the Flowering Plants of Nepal. The Natural History Museum, London.

Rai N.K. 1985. Peoples of the Stones; the Chepang of the Central Nepal. Center for Nepal and Asian Studies (CNAS), Tribhuvan University, Kathmandu, Nepal.

Sambatti J.B.M., Martins P.S. and Ando A. 2001. Folk taxonomy and evolutionary dynamics of cassava: a case study in Ubatuba, Brazil. Economic Botany 55(1): 93-105.

Somnasang P. and Moreno-Black G. 2000. Knowing, gathering and eating: knowledge and attitudes about wild food in an Isan village in NE Thailand. Journal of Ethnobiology 20: 197-216.

Thapaliya B.R. 1987. Chepang Jati Ek Parichaya. Gopal Thapaliya Dharan, Nepal (in Nepali).

Zhengyi W. and Raven P.H. 2000. Flora of China. Vol.24. Science Press, Beijing, China and Missouri Botanical Garden Press, St. Louis, USA. 